\title{
Measuring the usability of e-banking in Special Region of Yogyakarta
}

\author{
Anindyya Agripina Hadyanawati ${ }^{1, *}$, Ayudyah Eka Apsari ${ }^{2}$, and Hari Purnomo ${ }^{3}$ \\ 1,3 Industrial Engineering Departement, Universitas Islam Indonesia \\ ${ }^{2}$ Industrial Engineerin Departement, Universitas Islam Batik Surakarta
}

\begin{abstract}
Online shopping is become an option because customers do not need to go to the store. Internet banking is a bank facility to help customers in common. This research is aim to know usability aspect of ecommerce banking. Data collection was done by distributing questionnaires in Yogyakarta Special Region. The number of respondents is 140 with the range of age 17-22 years. Anova is used as method research. The results showed that in each group show significantly different. Post hoc analysis explained that learnability and efficiency variable has significantly different, with value $p<0,05$. The highest average value is in the learnability variable and the lowest is the memorability variable.
\end{abstract}

\section{Introduction}

Nowadays internet has grown in the last two decades and many used by education institution, business and finance institution. Education institution have been using internet to study. Social networking and online shop are used for business by the people (Laohapensang, 2009). Potential ecommerce is up to $77 \%$ which is used for search the information product and online shopping. While online shopping users reach 8,7 million people with the prediction of transaction value is US\$ 4,89 billion in 2016 (Kominfo, 2015). Shopping using internet is become an option because customers just only sit in front of the computer and make transaction via e-banking (Khodijah, 2013). Customer can also request the design with payment option using online (Ollie, 2008). According to Kotler (2002), the benefit of online service for the distributor are lower cost and adapt in market condition

Increasing number of e-commerce every year it easier for the people to search items through the internet. Buying item can using transaction via e-banking. Electronic banking is facility given by the bank for customer to get information. (Widiastuti, 2010). Application information technology in banking is used to processing the information and increase the service for customers. (Widiastuti, 2010) explained that quality system is significantly affect to customer's trust in increasing internet banking frequency usage.

Related research of internet banking is already studied. (Szopiński, 2016) stated the effect of e-banking. The use of e-banking is influenced by features, compatibility and service to consumers (Boateng, et al., 2016). And Ahmad \& Al-Zu'bi, (2011) research about e-banking features. (Oruç and Tatar, 2017) said that communication and convenience significantly influence e-banking.
Based on review related research about e-banking, then it is important to study about e-commerce banking usage. The purpose this research is to know about usability ecommerce banking. In addition to the result of this research can be used as a suggestion to improve the quality e-commerce banking. Improving the quality of ecommerce banking can affect the customers satisfaction. The level of satisfaction will be linear to the level of loyalty so that customers become loyal (Kassim dan Abdullah, 2010; Ahmad \& Al-Zu’bi, 2011)

\section{Method}

\subsection{Object and subject of research}

Object research is banking e-commerce in Yogyakarta, 140 banking e-commerce customers that using facilities e-banking are the subject of this research. Respondents with criteria (1) male and female (2) banking e-commerce usage (3) age between 18-50 years old.

\subsection{Method of collecting data}

Collecting data method is use observation and questionnaires. Observation technique in this research was done by direct observation of banking e-commerce and how to using e-banking. Questionnaire was distributed by google form as long as 2 months. Collecting data technique is using accidental sampling. Respondents selected according to specified criteria

\section{Questionnaire Variables}

The research variables in the questionnaire consist of five attributes: 
1. Learnability, with measurement indicator is internet banking is easy to learn and ease of accessing ebanking anywhere and anytime

2. Efficiency, with measurement indicator is website fast responds and completeness of the information provided

3. Memorability, with measurement indicator is website design layout and placement of menus available on the website easy to remember

4. Errors, with measurement indicator is server down frequency transaction failure

5. Satisfaction, with measurement indicator are satisfied with the systems of the services provided by the bank related

\section{Results and Discussion}

\subsection{Characteristic of respondents}

Respondents who fill questionnaires as many as 140 respondents with age between 17-22 years. Respondents with age 19 years are $42.5 \%$ percentage, followed with respondents with age of 18 years old are $22.5 \%, 27.5 \%$ at age 20 years, $5 \% 21$ years old and $2.5 \% 22$ years old. Respondents male is $50 \%$ and female $50 \%$

Differential tests result using anova for each variable are sown in Table 1 below

Table 1. Differential test result

\begin{tabular}{lccccc}
\hline \multicolumn{5}{c}{ ANOVA } \\
\hline & $\begin{array}{c}\text { Sum of } \\
\text { Squares }\end{array}$ & df & $\begin{array}{c}\text { Mean } \\
\text { Square }\end{array}$ & F & Sig. \\
\hline $\begin{array}{l}\text { Between } \\
\text { Groups }\end{array}$ & 8.584 & 4 & 2.146 & 2.666 & .034 \\
\hline $\begin{array}{l}\text { Within } \\
\text { Groups }\end{array}$ & 156.987 & 195 & .805 & & \\
\hline Total & 165.571 & 199 & & & \\
\hline
\end{tabular}

Based on the differential test result on Table 1 indicated that there is significantly differences between groups with $P$ value is $0,034(p>0,05)$. It explained that each variable has different value, the importance of the respondent to variable is different. The average value of each variable is shown in Figure 1.

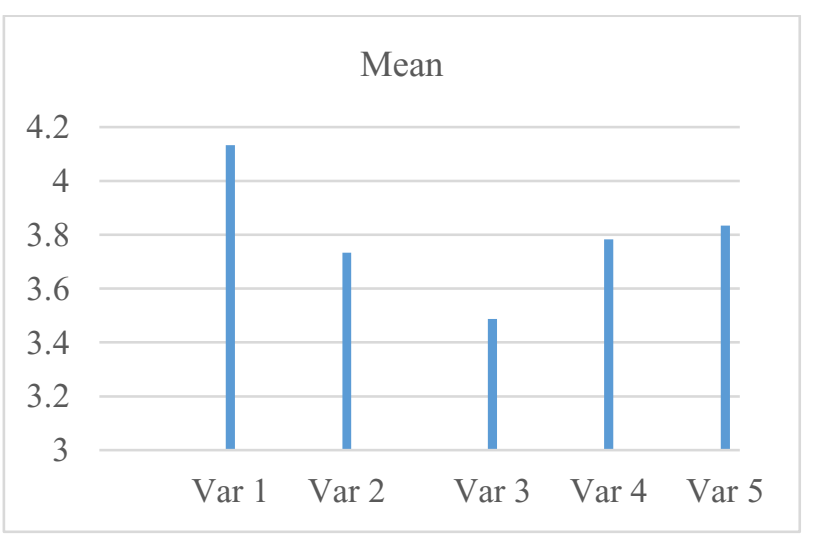

Figure 1. The mean of variables
Note:

Var1 : Learnability

Var2 : Efficiency

Var3 : Memorability

Var4 : Errors

Var5 : Satisfaction

Based on figure 1, the highest value is learnability with an average 4.13 . It can be explained that banking e commerce is very easy to use. The highest value is variable efficiency, variable errors and variable satisfaction has a little differential result with $\mathrm{p}$ value is $3.73 ; 3.78 ; 3.83$. This result is followed by Sangar and Rastari (2015) that explained Learnability, Satisfaction, and Efficiency is first grade factors. The lowest value is variable memorability with an average 3.49 explained that e-commerce is less memorable. All variables have value higher than 3 in scale 5 . This explained that learnability, efficiency, memorability, errors and satisfaction variable have good value in banking e-commerce application. Rastari and Sangar (2015) explained that usability is factor that need to improve for increase quality and efficiency. Independent pair t-test among variables can be seen in table 2.

Table 2. Independent pair t-test among variables

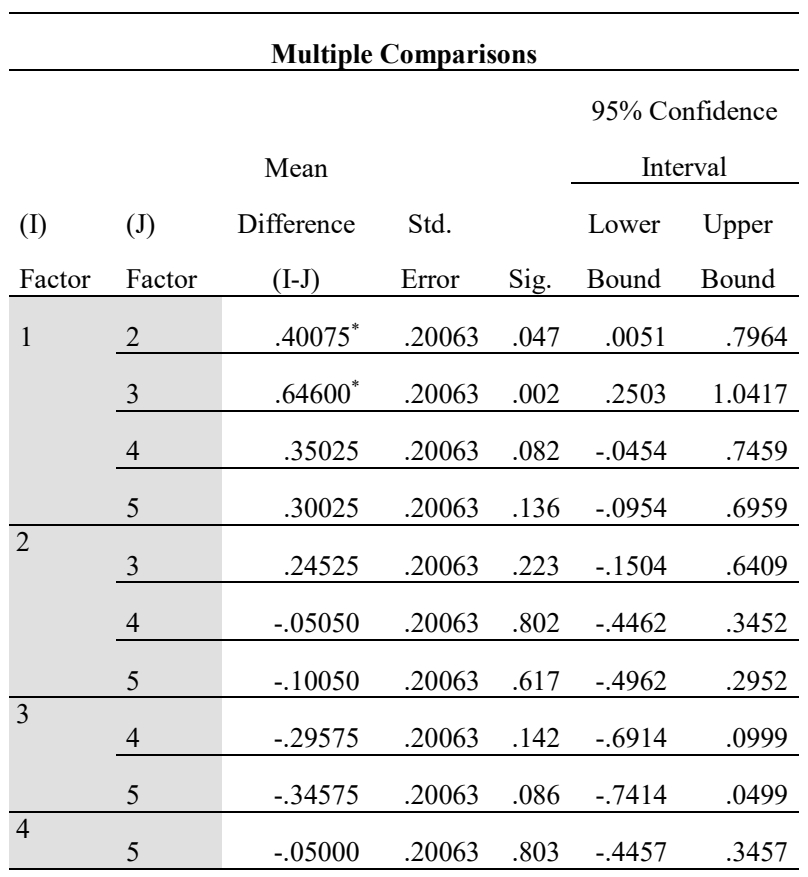

*. The mean difference is significant at the 0.05 level.

The result of independent pair t-test of variable 1 (learnability) and variable 2 (efficiency) is significantly different with $p$ value $0,047 \quad(p<0,05)$ with mean difference is 0,4 . Variable 1 (learnability) and variable 3 (memorability) are significantly different with $\mathrm{p}$ value $0,02(\mathrm{p}<0,05)$ with mean different 0,64 . Another variable has $p$ value $0,05(p>0,05)$

\section{Conclusion}

Respondent importance level in each variable has different value. Differential test result for groups there is 
significantly different with $\mathrm{p}$ value is 0,034 . Meanwhile, independent pair t-test shown that variable 1 (learnability) and variable 2 (efficiency) is significantly different with $p$ value is 0,047 and mean difference 0,4. Variable 1 (learnability) and variable 3 (memorability) is significantly different with $\mathrm{p}$ value 0,02 and mean difference 0.64. meanwhile, the other variables are not significantly different with $p$ value higher that 0,05 . Mean value of learnability has the highest value 4,13 and memorability has the lowest variable 3,49 . Variable 2,4 and 5 has the mean value 3,$73 ; 3,78 ; 3,83$, all variables has value higher that 3 of scale 5 . Then it's known that banking e-commerce is easy to use.

\section{References}

1. Laohanpengsang, O., "Factor influencing internet shopping behavior: a survey of consumers in Thailand." journal of fashion marketing and management vol.13 No.4,2009 pp.501-513 (2009)

2. Kementrian Komunikasi dan Informasi Republik Indonesia. Potensi Besar untuk Pemasukan Negara. Edisi XXI. Kominfo.go.id (2015)

3. Khodijah F.F., Analisis Pengaruh Kualitas Layanan dan Kualitas Produk terhadap Loyalitas Pelanggan pada Onlineshop menggunakan Structural Equation Modeling. Skripsi. Universitas Diponegoro. Semarang (2013)

4. F. De Lillo, F. Cecconi, G. Lacorata, A. Vulpiani, EPL, 84 (2008)

5. Widiastuti B. Studi tentang Intensitas Penggunaan Electronic Banking oleh Nasabah PT.Bank Central Asia (BCA) Kantor Cabang Utama Semarang. Tesis. Universitas Diponegoro. Semarang. (2010)
6. Szopiński T., S. Factors affecting the adoption of online banking in Poland. Journal of Business Research, Vol. 69 (11), p 4763-4768 (2016)

7. Boateng, H., Adam, D., R. Okoe ,A., F., AnningDorson, T. Assessing the determinants of internet banking adoption intentions: A social cognitive theory perspective. Computers in Human Behavior. Vol. 65, p. 468-478 (2016)

8. Ahmad, A.E.M.K. dan Al-Zu'bi, H.A., E-banking functionality and outcomes of customer satisfaction: an empirical investigation. International Journal of Marketing Studies, 3(1), pp.50-65 (2011)

9. Oruç, O., E., and Tatar, C. An investigation of factors that affect internet banking usage based on structural equation modeling. Computers in Human Behavior. Vol. 66, p 232-235 (2017)

10. Kassim, N. and Abdullah, N., A. The effect of perceived pervice quality dimensions on customer satisfaction, trust, and loyalty in e-commerce settings: A cross cultural analysis. Asia Pacific Journal of Marketing and Logistics, Vol. 22 Iss: 3, pp.351 - 371 (2010)

11. Sangar, A., B. and Rastari, S. A Model for Increasing Usability of Mobile Banking Apps on Smart Phones. Indian Journal of Science and Technology, Vol 8(30) (2015)

12. Rastari, S and Sangar, A., B. Investigating and comparing the usability models in the banking applications, Engineering Research Journal Vol 3, Issue 6, pp. 77-85 (2015) 